\title{
HEALTH-PROMOTING EFFECTS OF BIOACTIVE COMPOUNDS IN BLACKCURRANT (RIBES NIGRUM L.) BERRIES
}

\author{
Michat Oczkowski
}

Institute of Human Nutrition Sciences, Department of Dietetics, Warsaw University of Life Sciences (WULS-SGGW), Warsaw, Poland

\begin{abstract}
Blackcurrant (BC) is a well-known and appreciated berry fruit in our country and Poland is the largest BC producer among European Union countries and the second, after Russia, producer in the world. Due to the short shelf life of BC, its consumption in fresh form is relatively low , therefore the berries are processed into juices, jams, jellies, and freeze-dried products or alcoholic beverages. The high nutritional value of $\mathrm{BC}$ berries result from high content of bioactive compounds (among others, vitamin C, anthocyanins, pectins, organic acids, as well as polyunsaturated fatty acids contained in seeds of the fruit). Anthocyanins (ANTs) create the largest group among all polyphenolic compounds contained in BC. The results from different studies confirm that ANTs are important in attenuation oxidative stress parameters in the organism, and therefore can reduce the risk of certain non-communicable chronic diseases. Consumption of unprocessed and processed blackcurrants (i.e. juices and products containing fruit extracts) may support the nutrition therapy of cardiovascular diseases, certain eye diseases and may normalize the lipid profile of the blood plasma. Additionally, the beneficial profile of unsaturated fatty acids from BC seeds supports the therapy of autoimmune diseases. This article is attempts to summarize the results of the studies on the anti-inflammatory, immunomodulatory, anti-tumor and antimicrobial effects of $\mathrm{BC}$ bioactive compounds including the mechanisms of their action depending on the form of the fruit (e.g. juice, whole fruit extract, dried pomace, or seed oil). The article also highlights the potential use of BC in production of functional food, important in the dietary prevention of non-communicable chronic diseases resulting from increased oxidative stress in the organism.
\end{abstract}

Key words: anthocyanins, chemoprevention, blackcurrant, inflammation, oxidative stress, polyphenols

\section{STRESZCZENIE}

Czarna porzeczka jest znanym i cenionym owocem jagodowym, a Polska jest największym producentem tych owoców wśród krajów Unii Europejskiej i drugim po Rosji. Ze względu na nietrwałość owoców, ich spożycie w postaci świeżej jest stosunkowo niskie. Z tego też względu owoce czarnej porzeczki najczęściej przeznaczane są do produkcji soków, dżemów, galaretek oraz liofilizatów, suszów oraz napojów alkoholowych. Cenne, z żywieniowego punktu widzenia, właściwości owoców czarnej porzeczki wynikają z wysokiej zawartości związków o charakterze bioaktywnym (w tym m.in. witaminy $\mathrm{C}$, antocyjanów, pektyn i kwasów organicznych oraz wielonienasyconych kwasów tłuszczowych zawartych w pestkach owoców). Antocyjany, z kolei, stanowią największy udział spośród wszystkich związków polifenolowych zawartych w tych owocach. Wyniki badań potwierdzaja, że związki te sa istotne w przeciwdziałaniu skutkom stresu oksydacyjnego w organizmie, a zatem mogą zmniejszać ryzyko niektórych przewlekłych chorób niezakaźnych. Spożywanie czarnej porzeczki w formie surowej oraz przetworzonej, tj. soków oraz produktów zawierających ekstrakt z owoców może wspomagać dietoterapię chorób układu krążenia, niektórych chorób oczu oraz normalizować profil lipidowy osocza krwi. Dodatkowo, korzystny skład nienasyconych kwasów tłuszczowych zawartych w oleju z nasion owoców może wspomagać terapię chorób o podłożu autoimmunologicznym. Celem niniejszej pracy było podsumowanie badań dotyczących przeciwzapalnego, immunomodulującego, przeciwnowotworowego i przeciwdrobnoustrojowego wpływu związków bioaktywnych zawartych w czarnej porzeczce z uwzględnieniem mechanizmów ich działania w zależności od postaci owocu (tj. sok, suplementy zawierające ekstrakt z owoców, suszone wytłoki lub olej z pestek). Ponadto, w pracy zwrócono uwagę na potencjalne możliwości wykorzystania owoców czarnej porzeczki w produkcji żywności funkcjonalnej, mającej znaczenie w dietoprofilaktyce przewlekłych chorób niezakaźnych wynikających z nasilonego stresu oksydacyjnego w organizmie.

Słowa kluczowe: antocyjany, chemoprewencja, czarna porzeczka, polifenole, stan zapalny, stres oksydacyjny

Corresponding author: Michał Oczkowski, Szkoła Główna Gospodarstwa Wiejskiego w Warszawie, Instytut Nauk o Żywieniu Człowieka, Katedra Dietetyki, Zakład Fizjologii Żywienia, ul. Nowoursynowska 159c, 02-776 Warszawa, tel.: +48 22 5937031; e-mail: michal_oczkowski@sggw.edu.pl

C Copyright by the National Institute of Public Health NIH - National Research Institute 


\section{INTRODUCTION}

An optimal fruit intake is one of the factors in prevention of non-communicable chronic diseases. Fruit are one of most important group of food products that provides a substantial amount of bioactive compounds, therefore they should be a part of well-balanced diet. The results from recent research clearly report that regular optimal fruit consumption contributes to the lower risk of cardiovascular diseases, as well as a possible protective effect in decrease the risk of colon cancer, pancreatic diseases, mental health, attention and mood were also reported by other authors [5, 27, 68].

Considering the bioactive compounds present in fruits, the greater attention should be paid to blackcurrant (Ribes nigrum L.) (BC), a well-known and appreciated berry fruit in Poland. The long history of cultivation of $\mathrm{BC}$ in contributed to the greater popularity of these fruits in our country (both in home gardens and in horticulture production). A report of Main Statistic Office in Poland [26] estimated that the blackcurrant crops in recent years (2015-2019) obtained from orchards fluctuated and reached 130800 tons in 2016 and decreased to 92200 tons in 2019 [Fig. 1]. Poland is the leading $\mathrm{BC}$ berries producer in European Union countries and the second (after Russia) in the world. (as a waste of juice processing) are also used to produce a natural colorants or are a source of bioactive ingredients for production of many functional food products $[6,8,24,64]$.

The aim of this study was to summarize the research on the anti-inflammatory, immunomodulatory, antitumor and antimicrobial effects of bioactive compounds contained in blackcurrant, including the mechanisms of their action. In addition, the study highlights the potential use of $\mathrm{BC}$ fruit in the production of functional food of importance in the diet and prevention of chronic non-communicable diseases.

\section{NUTRITIONAL VALUE OF BC BERRIES}

The $\mathrm{BC}$ berries are a rich source of many bioactive and flavour compounds, like soluble sugars, vitamins, minerals, polyphenols, polyunsaturated fatty acids (PUFA), organic acids, vitamins (C, E), soluble and insoluble dietary fiber and tannins $[35,69]$. Nour et al. [49] showed, based on the analysis of the eight BC cultivars ('Abanos', 'Blackdown', 'Bogatar', 'Deea', 'Record', 'Ronix', 'Tenah' and 'Tinker') harvested in Romania, that the content of ascorbic acid in BC fruits ranged from $161.6 \pm 3.3$ to $284.5 \pm 1.5 \mathrm{mg} / 100$ of fresh weight (f.w.). In contrast, Rachtan-Janicka et al. [55] reported a lower values of vitamin $\mathrm{C}$ (ranging from

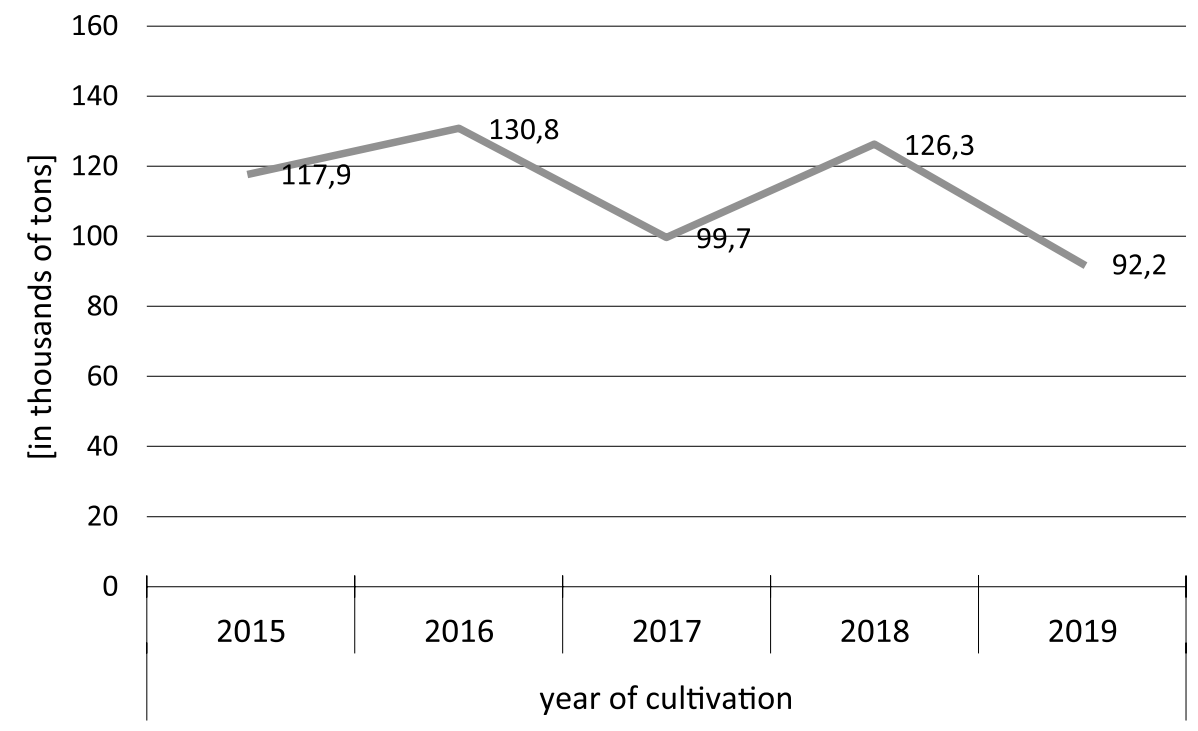

Figure 1. The harvest of blackcurrant fruit in horticulture in 2015-2019 [26]

A blackcurrant berries are known for their characteristic slightly tart and sour taste [6]. A blackcolored berries contain a high amount of anthocyanins (ANTs) [49]. Due to the rich source of sugars, pectin, and volatile compounds, $\mathrm{BC}$ berries are processed in a wide range of products (like juices, fruit nectars, jams, jellies, alcoholic and non-alcoholic beverages, and dry fruits) [17, 63]. Moreover, the fruit residues
$122.4 \pm 6.3$ to $155.9 \pm 3.2 \mathrm{mg} / 100$ f.w.) in 3 cultivars ('Adler', 'Tiben' and 'Titania') harvested in Poland. Blackcurrant fruits also contain a substantial amounts of minerals, especially potassium, magnesium and iron (ranging from: 251.1- 305.0; $45.7-65.9$ and $1.13-1.77$ $\mathrm{mg} / 100$ f.w., respectively). What is more interesting, BC seeds are rich in polyunsaturated fatty acids. As reported by Šavikin et al [59], linoleic acid (n-6) (39.6- 
46.9\%) was the most predominant essential fatty acid, following by $\gamma$-linolenic (n-6) (10.7-18.5\%), $\alpha$-linolenic (n-3) (12.9-16.9\%), stearidonic (n-3) (2.40-4.45\%), and oleic (n-9) $(9.86-13.39 \% \mathrm{w} / \mathrm{w})$. Furthermore, the n-3/n-6 essential fatty acids ratio amongst all analyzed blackcurrant cultivars was ranged from 0.27 to 0.36 .

In particular, an important health-promoting properties of $\mathrm{BC}$ result from the presence of polyphenolic compounds, that are plant secondary metabolites characterized by strong antioxidant activities. The most important polyphenols present in $\mathrm{BC}$ berries are flavonoids and anthocyanins. Environmental factors (such as, latitude, weather conditions and soil quality) significantly determine the quality of berries and as well as the level of bioactive metabolites in fruits [71]. The another key factor affecting the level of bioactive plant compounds is a cultivar variation. The analysis of phenolic compounds in $\mathrm{BC}$ berries of different cultivars originated from Scotland (UK), Lithuania, Latvia, Finland and Poland [67] revealed that level of total phenolics ranged from 598 to $2798 \mathrm{mg} / 100 \mathrm{~g}$, (dry weight, d.w.) and sum of ANTs varied from 532 to $2630 \mathrm{mg} / 100 \mathrm{~g}$ (d.w.). Also, Rachtan-Janicka et al. [55] showed the differences in the content of antioxidants compounds in $\mathrm{BC}$ fruits harvested in Poland, reporting a high level of phenolics (166-198 mg/100 g f.w.) and anthocyanins (146-179 $\mathrm{mg} / 100 \mathrm{~g}$ f.w.) in BC berries with the highest level of these compounds observed in 'Titania' cultivar.

\section{HEALTH BENEFITS OF BLACKCURRANT ANTHOCYANINS}

Anthocyanins (ANTs) are found mainly in blackcurrant fruit skins, but in small amount they also present in leaves [65] and constitute nearly $90 \%$ of total polyphenolic compounds present in BC [17]. In addition, 3-O-rutinoside and 3-O-glucoside of cyanidin and delphinidin are the major ANTs [Fig. 2] [15], however they are known from its low bioavailability. The results from the study of Röhrig et al. [58] with 5 healthy volunteers (aged 24-32 years) showed that the a single ingestion of $1.5 \mathrm{~g} \mathrm{BC}$ extract (dissolved in a volume of $200 \mathrm{~mL}$ ) containing delphinidin-3rutinoside and cyanidin-3-rutinoside (at a dose of $190 \pm 7 \mathrm{mg}$ and $172 \pm 8$, respectively) showed a highest plasma and urine ANTs concentration after two hours of ingestion, but the recoveries of both tested bioactive compounds in urine samples were $0.04 \pm 0.01 \%$ (for delphinidin-3-O-rutinoside) and $0.048 \pm 0.016 \%$ (for cyanidin-3-O-rutinoside). The ANTs exert in organism a direct effects through the intestinal absorption or they may influence indirectly via microbiota environment<smiles>O=C([O-])c1cc2c(O)cc(O)cc2[o+]c1-c1ccc(O)c(O)c1</smiles>

cyanidin-3-O-glucoside<smiles>O=C([O-])c1cc2c(O)cccc2[o+]c1-c1cc(O)c(O)c(O)c1</smiles>

delphinidin-3-O-glucoside<smiles>C[C@@H](c1ccccc1)c1cc2c(O)cccc2[o+]c1-c1ccc(O)c(O)c1</smiles>

cyanidin-3-0-rutinoside<smiles>CCOCCOCCOc1cccc(O)c1-c1cc2ccccc2[o+]c1-c1cc(O)c(O)c(O)c1</smiles>

Figure 2. The chemical structure of the main anthocyanins in blackcurrant 
[22]. It is known that human microbiota participate in enzymatic bioconversion of bioactive compounds and contributes to its higher antioxidative potential [66]. Despite of its low plasma concentration, ANTs reveal a significant health-promoting properties.

Oxidative stress (OS) is a state of accumulation of reactive oxygen species (ROS) and is observed as a result of an imbalance between pro-oxidative and antioxidant processes. It occurs as a result of excessive production or insufficient degradation of ROS. The biological consequences of oxidative stress include changes in gene expression, inhibition of proliferation, disruption in intercellular communication, that lead to tissue damage and organs dysfunction [31].

The findings from in vivo [11], in vitro [18] and clinical $[13,25]$ studies demonstrate a protective role of polyphenols in exerting anti-oxidative effects that decrease the risk of certain non-communicable chronic diseases (chronic inflammatory diseases, some type of cancers, atherosclerosis, type 2 diabetes, neurodegenerative diseases) [61]. Consumption a raw and processed blackcurrants (i.e. juices and products with fruit extract), may support the nutrition therapy of cardiovascular diseases, eye diseases and normalize the lipid profile of the blood plasma and obesity) [33, $38,39,57]$. Additionally, the beneficial composition of unsaturated fatty acids present in fruit seed may support the treatment of autoimmune diseases [14].

\section{ANTI-INFLAMMATORY EFFECTS OF BLACKCURRANT}

Inflammation is a complex reaction of organism caused by exogenous (pathogens, allergens, irritants or toxic substances) and endogenous (signals coming from stressed cells, damaged tissues or extracellular matrix breakdown) factors [46]. The mediators of inflammatory pathway (pro-inflammatory cytokines and chemokines, bioactive amines, eicosanoids and bradykinin) can make functional changes in many tissues. The acute phase of inflammation can manifest as swelling, pain, redness, heat or tissue malfunction. When an inflammatory response is triggered by an infection, an immune response is induced by engaging a specific immune cells (like monocytes/macrophages and neutrophils). [45]. This process is mediated by enzyme (cyclooxygenase 2, COX-2) that transforms arachidonic acid to pro-inflammatory prostaglandins (eicosanoids) [56].

Anti-inflammatory potential of $\mathrm{BC}$ polyphenols has been widely investigated during last years. A promising results regarded $\mathrm{BC}$ treatment come from experiments with obesity-associated inflammation [34]. Diet-induced obesity in animal models is a well-known causative agent of moderate systemic inflammation. Lee et al. [38] investigated the effects of $\mathrm{BC}$ extract $(\mathrm{BCE})$ in a mice model of obesityinduced nonalcoholic steatohepatitis. The authors reported that feeding mice (for 24 weeks) with $6 \%$ of whole blackcurrant extract with high-fat/high-sucrose (HFHS) diet caused an inhibition of pro-inflammatory M1 macrophages infiltration in the liver and downregulated the hepatic Tlr4 (toll-like receptor) gene expression when compared with feeding with HFHS diet alone. Moreover, BCE significantly reduced liver weights and triacylglycerol accumulation in liver. The similar results were also obtained by Nanashima et al. [48] in the study with ovariectomized (OVX) SpragueDawley female rats. A 3-month dietary experiment, during which the rats were fed with AIN-93M feed with $3 \%$ of $\mathrm{BCE}$ (as commercially available supplement contained $38 \mathrm{~g} / 100 \mathrm{~g} \mathrm{BCE}$ ) revealed a lower gene expression of pro-inflammatory cytokines (Tnfa, $I l 6$ and $I l b$ ) in OVX rats compared to control fed group. The improvement in cytokines genes expression were also accompanied by a favorable histological indices in liver. The NAFLD (nonalcoholic fatty liver disease) activity score was markedly decreased in rats fed with BCE compared with control OVX group. In turn, ANTs-rich BC extract ("Currantex 30"; $10 \mu \mathrm{g} / \mathrm{mL}$ total anthocyanins) has been shown to inhibit inflammation response in lungs, eosinophilia, and CCL2 chemokine release in a mouse model of ovoalbumin-induced airway system inflammation. Moreover, the flowcytometry analysis revealed a significant decrease in total infiltrating immune cells in lungs of mice exposed to inflammation and simultaneously treated with BC extract [62].

In vitro studies with ANTs also confirm a significant impact in alleviation of chronic inflammation through the inhibition of NF- $\kappa$ B signaling. Ferrari et al. [23] reported a protective role of cyanidin-3-O-glucoside in an acute in vitro model of inflammation. The colon cancer epithelial (Caco-2) cells were exposed to TNFa to induce the mediators of inflammation, and pretreatment the cells with cyanidin-3-O-glucoside (20$40 \mu \mathrm{M}$ for 24 hours) reversed the changes induced by TNF $\alpha$. There was also observed an inhibition of acute inflammation via down-regulation of IL-6 mRNA and COX-2 protein expression in colon cells after the exposure to cyanidin-3-O-glucoside. In addition, ANT treatment was also able to induce the expression of Nrf2 transcription factor in order induce the anti-oxidative mechanisms. The similar results were also reported by Olejnik et al. [50]. The gastrointestinal digested a freeze-dried $\mathrm{BC}$ powder $(1 \mathrm{mg} / \mathrm{mL})$ down-regulated (by 54\%) IL-8 and COX2 (by 17\%) expression in Caco-2 cells. Moreover, there were also observed anti-inflammatory effects in RAW264.7 macrophages. A down-regulation of IL1 $\alpha$ (by 76\%), IL-1 $\beta$ (by 91\%), IL-6 (by 61\%), TNF $\alpha$ and 
COX-2 expression in LPS-stimulated macrophages in response to $\mathrm{BC}$ fruit extract was also noted.

The results from other in vitro studies have been proposed a positive effects of $\mathrm{BC}$ polyphenolic compounds in alleviation of lung inflammation and risk of allergic asthma. Hurst et al. [28], using a human alveolar epithelial (A549) cells, investigated the effects of BC ANTs and proanthocyanidins on eotaxin-3 (CCL26). This chemokine is highly expressed upon stimulation by IL-4 and IL-13 derived from activated Th2 cells, what is frequently observed in asthma patients. What is more, the beneficial effect seemed to be more pronounced for $\mathrm{BC}$ proanthocyanidins than for ANTs.

Of the large body of research regarding the antiinflammatory effects of $\mathrm{BC}$, there are still little evidence from clinical and epidemiological studies, and existing findings bring contradictory results. A randomized, double-blind, placebo-controlled cross-over ANTHONIA study [37] with 30 healthy female students (aged 24.6 \pm 1.2 years) did not reveal any significant changes in inflammatory markers (TNF- $\alpha$, monocyte chemoattractant protein-1 (MCP1), high-sensitive C-reactive peptide (hs-CRP), IL-2, IL-6, IL-8, and IL-10) after a 14-day intervention with anthocyanin-rich juice or smoothie (contained $840 \pm 10$ or $983 \pm 37 \mathrm{mg} / \mathrm{mL}$ ANTs in a volume of $330 \mathrm{~mL} / \mathrm{d}$, respectively). In contrast, Aboonabi and Aboonabi [1] reported that a 4-week dietary intervention (with $320 \mathrm{mg} /$ day of ANTs extracted from wild Norwegian bilberries and blackcurrant) in patients with metabolic syndrome showed significant anti-inflammatory effects. ANTs supplementation caused a downregulation of $\mathrm{Nf}-\mathrm{\kappa B}$-depended pro-inflammatory cytokines (TNF- $\alpha$, IL- $1 \alpha$ and IL-6), as well as COX2 gene expression in blood cells. Moreover, the another paper from the same study of Aboonabi et al. [2] revealed significant reduction of serum hs-CRP following ANTs dietary intervention. The effects of BC ANTs on selected NF- $\mathrm{kB}-$ related chemokines were reported in the study conducted by Karlsen et al [30]. A group of 118 healthy men and women (aged 40-74 years) were treated with Medox ${ }^{\circledR}$ capsules (300 $\mathrm{mg} / \mathrm{d}$ for 3 weeks; $\mathrm{n}=59$ ) with purified ANTs from bilberry and blackcurrant or were subjected to placebo $(\mathrm{n}=59)$. There was observed a significant reduction in plasma pro-inflammatory IL-8 (CXCL8) cytokine, RANTES (CCL5) and INF $\alpha$ (NF- $\mathrm{BB}$ activation inducer) chemokines.

The subclinical endothelium inflammation is a pivotal factor increasing the risk of atherosclerosis. The pro-oxidant state in endothelium contributes to the modification of monocytes into foam cells (macrophages that absorb oxLDL, oxidized lowdensity lipoproteins), that release the reactive oxygen species and stimulate the cell adhesion molecules.
The study of Khan et al. [32] performed among 64 healthy adults who consumed a drink $(250 \mathrm{ml}, 4$ times a day for 6 weeks) with lower or higher content of $\mathrm{BC}$ juice $(6.4 \% \mathrm{BC}$ juice with $4 \mathrm{mg} / 100 \mathrm{ml}$ total anthocyanins or $20 \%$ BC juice with $14.3 \mathrm{mg} / 100 \mathrm{ml}$ total anthocyanins, respectively) compared to placebo drink. The volunteers, who have consumed BC drink with higher anthocyanins level revealed a decreased flow-mediated dilation (FMD\%), a parameter related to endothelial reactivity, and lower plasma F2isoprostanes level (a marker of oxidative stress), compared to placebo group.

\section{ANTI-CANCER PROPERTIES OF BLACKCURRANT}

The chemopreventive activity of $\mathrm{BC}$ bioactive compounds extensively studied by different authors in in vitro and in vivo experiments are related to multiple mechanisms [19, 53]. The ANTs possess the ability to arrest a cell cycle and induce apoptosis [44, 47], reduce the risk of DNA damage, and exert an anti-mutagenic action [70].

Diaconeasa et al. [20] studied the anti-proliferative effects (using MTT assay) of ANT extract obtained from $\mathrm{BC}$ juice on murine melanoma (B16F10), ovarian carcinoma (A2780) and cervical cancer (HeLa) cell lines. The glycosylated ANTs from BC revealed a dose-dependent reduction in cell proliferation with $\mathrm{IC}_{50}$ values of $224 \mu \mathrm{g} / \mathrm{mL}, 259.8 \mu \mathrm{g} / \mathrm{mL}$ and $281 \mu \mathrm{g} /$ $\mathrm{mL}$ (in case of B16F10, A2780, and HeLa cells, respectively). It is commonly known that chronic oxidative stress and inflammation cause a higher risk of tumorigenesis. Moreover, the imbalance in redox state in the cells (oxidative environment) stimulates transcription of antioxidative enzymes. This process is controlled at transcriptional level via c-active sequences (antioxidant response elements, ARE) that are regulated mainly by Nrf2 transcriptional factor [12]. Anthocyanins, due to their three hydroxyl groups on B-ring and one on C-ring, can act with antioxidant response elements (ARE) via Keap1-Nrf2 signaling pathway and stimulate the expression of antioxidative enzymes (such as glutathione reductase, glutathione peroxidase, glutathione transferase and quinone oxidoreductase) [43]. The promising findings on anticancer properties of ANTs were shown by $L i$ et al. [42]. The authors tested the combined effects of cisplatin $(5 \mu \mathrm{g} / \mathrm{mL})$ and cyanidin-3-O-glucoside $(400 \mu \mathrm{g} / \mathrm{mL})$ on HeLa cells and observed that the combination of two substances inhibits the proliferation more distinctively compared to the administration of cisplatin alone. Cyanidin-3-O-glucoside in combination with chemotherapeutic drug contributed to more increased apoptosis and cell cycle arrest in G1 phase than it was observed following cisplatin treatment. It can be 
postulated that flavonoids could enhance the activity of chemotherapy drugs. A similar, promising results of anti-tumor properties of ANTs were reported by $L i$ et al. [41], who conducted in vitro experiments with human epidermal growth factor receptor 2 (HER2)-positive breast cancer cell lines (MDA-MB-453, BT474, and MDA-MB-453R, BT474R as trastuzumabresistant lines). The cells were exposed to cyanidin3-O-glucoside and peonidin-3-O-glucoside (P3G) at concentration ranged from 0.003 to $50 \mu \mathrm{M}$. Both tested ANTs (at $5 \mu \mathrm{M}$ concentration) downregulated phosphorylation of HER-2, AKT (Ser473) and p44/42 MAPK (mitogen-activated protein kinase) kinases. Furthermore, the 24- and 48-hour exposure the cells to cyanidin-3-O-glucoside $(5 \mu \mathrm{M})$ and peonidin-3-Oglucoside $(5 \mu \mathrm{M})$ resulted in increased apoptosis. The overexpression of the HER2 gene is responsible for a poor prognosis of recovery form breast cancer, as well as increased risk of an invasive stage and tumor metastasis. The beneficial antiproliferative effect of BC extract was investigated by Olsson et al. [51] who showed a concentration-dependent $(0.025-0.5 \%)$ reduction in cell proliferation of human colon cancer HT29 line. What is more, due to high concentration of vitamin $\mathrm{C}$ in $\mathrm{BC}$ extract, a synergistic anti-proliferative effect of both vitamin $\mathrm{C}$ and ANTs can be postulated.

Studies conducted in animal models with experimentally-induced tumors have also provided a convincing evidence of chemopreventive effect of $\mathrm{BC}$ extract $[9,25]$. In the study conducted by Bishayee et al. [10], male Sprague-Dawley rats fed with diet supplemented with BC skin extract (BCSE; 100 or $500 \mathrm{mg} / \mathrm{kg}$ of body weight) were subjected to dietylnitrosoamine (DENA)-induced hepatocellular carcinoma. The macroscopic observations revealed a significantly lower incidence of liver nodules in rats feeding with diet with higher BCSE content compared to DENA exposed animals. The liver specimens from rats in DENA group demonstrated a significantly higher value of proliferative nuclear antigen(PCNA)-positive cells score (a marker of increased cell proliferation) than animals treated with BCSE (at $500 \mathrm{mg} / \mathrm{kg} \mathrm{bw}$ ). At the same time, a higher liver apoptotic index in the liver was observed in animals fed with feed with higher content of BCSE versus DENA control group.

\section{ANTI-MICROBIAL ACTIVITIES OF BC ANTHOCYANINS}

The antimicrobial activities of dietary plant bioactive compounds against pathogenic bacteria have been extensively reviewed by many authors [3, $16,54]$. Regarding the polysaccharides present in blackcurrant seeds, Lengsfeld et al. [40] in in vitro study observed a lower adhesion rate of Helicobacter pylori to gastric mucosa. The anti-adhesive properties of raw polysaccharides from $\mathrm{BC}$ seeds result from the presence of acidic high-molecular weight galactans, which are able to bind to H. pylori receptors, and thus can inhibit their ability to implementation in gastric epithelium. In turn, Kranz et al. [36] showed an efficient antimicrobial activity of $\mathrm{BC}$ extract in suppression of oral Porphyromonas gingivalis, Aggregatibacter actinomycetemcomitans, Actinomyces naeslundii, Fusobacterium nucleatum bacteria colonization compared with $0.2 \%$ chlorhexidine, an antimicrobial agent commonly used in mouthwashes. It is postulated that a natural compounds from $\mathrm{BC}$ might be a promising tool in the prevention of periodontitis. The findings from a 6-week in vivo experiment (with Sprague Dawley male rats) [52] proved that $\mathrm{BC}$ anthocyanins can modify the intestinal bacterial microbiota. The BC extract (Currantex; 32\% w/w of total ANTs content) added to the rats feed (at a dose of $40 \mathrm{~g} / \mathrm{kg}$ ) caused a higher relative abundance of Bacteroides-Prevotella-Porphyromonas group and Lactobacillus spp., and lower Bifidobacterium spp. Clostridium perfringens.

\section{POSSIBILITIES OF A PRACTICAL USE OF PHENOLIC COMPOUNDS FROM THE WASTEBLACKCURRANT PRODUCTS}

The processing of $\mathrm{BC}$ fruit offers an enormous possibility of reusing the $\mathrm{BC}$ waste products as valuable functional additives in food. Baranowski et al. [8] noticed that residue after $\mathrm{BC}$ juice production may be a nutritive additive to "ice" fruit tea or jellies. $\mathrm{BC}$ pomace is a rich source of phenolic compounds, especially anthocyanins (up to $49 \% \mathrm{w} / \mathrm{w}$ ) from fruit skins [29], soluble $(28-30 \% \mathrm{w} / \mathrm{w})$ and insoluble $(47 \% \mathrm{w} / \mathrm{w})$ dietary fiber [4], essential fatty acids and phytosterols [21] present in seeds.

The cereal-based products are a very popular food products that are enriched with BC to increase organolepic and nutrition value. Gagneten et al. [24] reported that the fortification of gluten-free cookies with of $3.75 \%$ of $\mathrm{BC}$ extract from by-product after juice production caused an $62 \%$ increase in total phenolic content without any negative organoleptic changes. The same, Shmidt et al. [60] proposed to enrich a savoury crackers in $\mathrm{BC}$ pomace. The flour replacement even up to $30 \%$ can still make an acceptable product for consumers.

The effects of consumption dietary extract from $\mathrm{BC}$ pomace rich in antioxidants was also studied in in vivo models [29]. The experiment conducted on 20 New Zealand white rabbits confirmed that feed supplementation with $1.5 \%$ of $\mathrm{BC}$ pure extract from pomace reduced insulin resistant markers,plasma 
triglyceride and total cholesterol concentration in animals maintained on a high-fat diet.

\section{CONCLUSIONS}

Based on the research conducted in recent years, BC fruits demonstrate a significant therapeutic potential. The anti-inflammatory, anti-oxidative and anti-cancer properties of $\mathrm{BC}$ have been confirmed in many studies. There is still a little evidence coming from human clinical and randomized controlled studies about the beneficial effects of $\mathrm{BC}$ polyphenolic compounds, therefore the extrapolation the results obtained from in vitro and in vivo models to humans should be made with caution. Undoubtedly, blackcurrant fruits consumed at optimal amounts as fresh or used as by-products after juice production additives or supplements exert the anti-oxidative effects and therefore can be used in prophylaxis of many non-communicable chronic diseases, as well as can be used as therapeutic factor to diminish chronic inflammation. A further research perspectives on $\mathrm{BC}$ compounds should concern on the mechanisms of anti-cancer activity and the possibility of designing preparations containing blackcurrant to support cancer therapy.

\section{Conflict of interest}

The author declares no conflict of interest.

\section{Acknowledgements}

This research was funded by the Polish Ministry of Education and Science within funds of Institute of Human Nutrition Sciences, Warsaw University of Life Sciences (WULS), for scientific research.

\section{REFERENCES}

1. Aboonabi A., Aboonabi A.: Anthocyanins reduce inflammation and improve glucose and lipid metabolism associated with inhibiting nuclear factor-kappaB activation and increasing PPAR- $\gamma$ gene expression in metabolic syndrome subjects. Free Radic Biol Med 2020;150:30-39 doi: 10.1016/j. freeradbiomed.2020.02.004.

2. Aboonabi A., Meyer R.R., Gaiz A., Singh I.: Anthocyanins in berries exhibited anti-atherogenicity and antiplatelet activities in a metabolic syndrome population. Nutr Res 2020;76:82-93 doi: 10.1016/j.nutres.2020.02.011.

3. Abouzeed Y.M., Zgheel F., Elfahem A.A., Almagarhe M.S., Dhawi A., Elbaz A., Hiblu M.A., Kammon A., Ahmed M.O.: Identification of phenolic compounds, antibacterial and antioxidant activities of raisin extracts. Open Vet J 2018;8(4):479-484 doi: 10.4314/ovj.v8i4.20.

4. Alba K., Macnaughtan W., Laws A.P., Foster T.J., Campbell G.M., Kontogiorgos V.: Fractionation and characterisation of dietary fibre from blackcurrant pomace. Food Hydrocoll 2018;81:398-408 doi:10.1016/j. foodhyd.2018.03.023.

5. Angelino D., Godos J., Ghelfi F., Tieri M., Titta L., Lafranconi A., Marventano S., Alonzo E., Gambera A., Sciacca S., Buscemi S., Ray S., Galvano F., Del Rio $D$., Grosso G.: Fruit and vegetable consumption and health outcomes: An umbrella review of observational studies. Int J Food Sci Nutr 2019; 70(6): 652-667 doi: 10.1080/09637486.2019.1571021.

6. Archaina D., Leiva G., Salvatori D., Schebor C.: Physical properties of spray-dried powders from blackcurrant juice and extracts obtained from the waste of juice processing. Food Sci Technol Int 2017;24(1):7886 doi: 10.1177/1082013217729601.

7. Archaina D., Sosa N., Rivero R., Schebor C.: Freezedried candies from blackcurrant (Ribes nigrum L.) and yoghurt. Physicochemical and sensorial characterization. LWT 2019;100: 444-449. doi: 10.1016/j.lwt.2018.10.049.

8. Baranowski K., Baca E., Salamon A., Michalowska D., Meller D., Karas M.: Możliwości odzyskiwania i praktycznego wykorzystania związków fenolowych z produktów odpadowych: $\mathrm{z}$ wytłoków z czarnej porzeczki $\mathrm{i}$ aronii oraz $\mathrm{z}$ chmielin [Possibilities of retrieving and making a practical use of phenolic compounds from the waste products: blackcurrant and chokeberry pomace and spent hops]. Żywność Nauka Technologia Jakość 2009;4(65): 100 - 109 (in Polish).

9. Bishayee A, Háznagy-Radnai E, Mbimba T, Sipos P, Morazzoni P, Darvesh AS, Bhatia D, Hohmann J.: Anthocyanin-rich black currant extract suppresses the growth of human hepatocellular carcinoma cells. Nat Prod Commun 2010;5(10):1613-8.

10. Bishayee A, Mbimba T, Thoppil RJ, Háznagy-Radnai E, Sipos P, Darvesh AS, Folkesson HG, Hohmann J.: Anthocyanin-richblack currant(RibesnigrumL.) extract affords chemoprevention against diethylnitrosamineinduced hepatocellular carcinogenesis in rats. J Nutr Biochem 2011;22(11):1035-46 doi: 10.1016/j. jnutbio.2010.09.001.

11. Bishayee A, Thoppil RJ, Mandal A, Darvesh AS, Ohanyan $V$, Meszaros JG, Háznagy-Radnai E, Hohmann J, Bhatia D.: Black currant phytoconstituents exert chemoprevention of diethylnitrosamineinitiated hepatocarcinogenesis by suppression of the inflammatory response. Mol Carcinog 2013;52(4):304317 doi: $10.1002 / \mathrm{mc} .21860$.

12. Biswas M, Chan JY.: Role of Nrf1 in antioxidant response element-mediated gene expression and beyond. Toxicol Appl Pharmacol 2010; 244(1):16-20 doi: 10.1016/j.taap.2009.07.034.

13. Braakhuis AJ, Hopkins WG, Lowe TE.: Effects of dietary antioxidants on training and performance in female runners. Eur J Sport Sci 2014;14(2):160-168 doi: 10.1080/17461391.2013.785597.

14. Cameron M, Gagnier JJ, Little CV, Parsons TJ, Blümle A, Chrubasik S.: Evidence of effectiveness of herbal medicinal products in the treatment of arthritis. Part 2: Rheumatoid arthritis. Phytother Res 2009;23(12):16471662 doi: $10.1002 /$ ptr.3006. 
15. Cao L., Park Y., Lee S., Kim D.O.: Extraction, Identification, and Health Benefits of Anthocyanins in Blackcurrants (Ribes nigrum L.). Appl Sci 2021;11(4), 1863 doi: 10.3390/app11041863.

16. Cesoniene L, Jasutiene I, Sarkinas A.: Phenolics and anthocyanins in berries of European cranberry and their antimicrobial activity. Medicina (Kaunas) 2009;45(12):992-9

17. Cortez R.E., Gonzalez de Mejia E.: Blackcurrants (Ribes nigrum): A Review on chemistry, processing, and health benefits. J food Sci 2019;84(9), 2387-2401 doi: 10.1111/1750-3841.14781.

18. Desjardins J., Tanabe S., Bergeron C., Gafner S., Grenier D.: Anthocyanin-rich black currant extract and cyanidin-3-O-glucoside have cytoprotective and antiinflammatory properties. J Med Food 2012;15(12):10451050 doi: 10.1089/jmf.2011.0316.

19. Dharmawansa K.V.S., Hoskin D.W., Rupasinghe H.P.V.: Chemopreventive Effect of Dietary Anthocyanins against Gastrointestinal Cancers: A Review of Recent Advances and Perspectives. Int $\mathrm{J}$ Mol Sci. 2020;21(18):6555 doi:10.3390/ijms21186555.

20. Diaconeasa Z., Leopold L., Rugină D., Ayvaz H., Socaciu $C$.: Antiproliferative and antioxidant properties of anthocyanin rich extracts from blueberry and blackcurrant juice. Int J Mol Sci 2015;16(2):2352-2365 doi:10.3390/ijms16022352.

21. Dobson G., Shrestha M., Hilz H., Karjalainen R., McDougall G., Stewart D.: Lipophilic components in black currant seed and pomace extracts. Eur J Lipid Sci Tech 2012;114(5), 575-582. doi: 10.1002/ejlt.201100313.

22. Fernandes I., Faria A., Calhau C., de Freitas V., Mateus, $N$ : Bioavailability of anthocyanins and derivatives. $\mathrm{J}$ Func Foods 2014; 7, 54-66. doi: 10.1016/j.jff.2013.05.010.

23. Ferrari D, Speciale A, Cristani M, Fratantonio D, Molonia MS, Ranaldi G, Saija A, Cimino F.: Cyanidin3-O-glucoside inhibits NF-kB signalling in intestinal epithelial cells exposed to TNF- $\alpha$ and exerts protective effects via Nrf2 pathway activation. Toxicol Lett 2016;264:51-58 doi: 10.1016/j.toxlet.2016.10.014.

24. Gagneten M., Archaina D.A., Salas M.P., Leiva G.E., Salvatori D.M., Schebor C.: Gluten-free cookies added with fibre and bioactive compounds from blackcurrant residue. Food Sci Technol Int 2021;56(4),1734-1740 doi: 10.1111/ijfs.14798.

25. Gopalan A., Reuben S.C., Ahmed S., Darvesh A.S., Hohmann J., Bishayee A.: The health benefits of blackcurrants. Food Funct 2012;3(8):795-809 doi: 10.1039/C2FO30058C.

26. GUS, Production of agricultural and horticultural crops in 2019, Statistics Poland, Warsaw 2020

27. Guzek D., Gtabska D., Groele B., Gutkowska K.: Fruit and Vegetable Dietary Patterns and Mental Health in Women: A Systematic Review. Nutr Rev 2021 doi: 10.1093/nutrit/nuab007

28. Hurst S.M., McGhie T.K., Cooney J.M., Jensen D.J., Gould E.M., Lyall K.A., Hurst R.D.: Blackcurrant proanthocyanidins augment IFN-gamma-induced suppression of IL-4 stimulated CCL26 secretion in alveolar epithelial cells. Mol Nutr Food Res 2010; 54 Suppl 2:S159-170 doi: 10.1002/mnfr.200900297.

29. Jurgoński A., Juśkiewicz J., Zduńczyk Z., Matusevicius P., Kołodziejczyk K.: Polyphenol-rich extract from blackcurrant pomace attenuates the intestinal tract and serum lipid changes induced by a high-fat diet in rabbits. Eur J Nutr 2014;53(8):1603-1613 doi: 10.1007/ s00394-014-0665-4.

30. Karlsen A., Retterstøl L., Laake P., Paur I., Bøhn S.K., Sandvik L., Blomhoff R.: Anthocyanins inhibit nuclear factor-kappaB activation in monocytes and reduce plasma concentrations of pro-inflammatory mediators in healthy adults. J Nutr 2007;137(8):1951-1954 doi: 10.1093/jn/137.8.1951.

31. Karolkiewicz J.: Wpływ stresu oksydacyjnego na strukturę i funkcję komórek oraz konsekwencje wynikające z uszkodzeń wolnorodnikowych - związek $\mathrm{z}$ procesami starzenia [Effects of oxidative stress and free-radicalmediated damage on cell structure and function - connection to aging processes]. Gerontol Pol 2011;19(2):59-67 (in Polish).

32. Khan F., Ray S., Craigie A.M., Kennedy G., Hill A., Barton K.L., Broughton J., Belch J.J.: Lowering of oxidative stress improves endothelial function in healthy subjects with habitually low intake of fruit and vegetables: a randomized controlled trial of antioxidant- and polyphenol-rich blackcurrant juice. Free Radic Biol Med 2014;72:232-237 doi: 10.1016/j. freeradbiomed.2014.04.006.

33. Khoo H.E., Ng H.S., Yap W.S., Goh H.J.H., Yim H.S.: Nutrients for Prevention of Macular Degeneration and Eye-Related Diseases. Antioxidants (Basel) 2019;8(4):85 doi: 10.3390/antiox8040085.

34. Kim B., Lee S.G., Park Y.K., Ku C.S., Pham T.X., Wegner C.J., Yang Y., Koo S.I., Chun O.K., Lee J.Y.: Blueberry, blackberry, and blackcurrant differentially affect plasma lipids and pro-inflammatory markers in diet-induced obesity mice. Nutr Res Pract 2016;10(5):494-500 doi: 10.4162/nrp.2016.10.5.494.

35. Kowalski R, Gonzalez de Mejia E.: Phenolic composition, antioxidant capacity and physical characterization of ten blackcurrant (Ribes nigrum) cultivars, their juices, and the inhibition of type 2 diabetes and inflammation biochemical markers. Food Chem 2021;359:129889 doi: 10.1016/j.foodchem.2021.129889.

36. Kranz S., Guellmar A., Olschowsky P., TonndorfMartini S., Heyder M., Pfister W., Reise M., Sigusch B.: Antimicrobial Effect of Natural Berry Juices on Common Oral Pathogenic Bacteria. Antibiotics (Basel). 2020; 24;9(9):533 doi: 10.3390/antibiotics9090533.

37. Kuntz S., Kunz C., Herrmann J., Borsch C.H., Abel G., Fröhling B., Dietrich H., Rudloff S.: Anthocyanins from fruitjuicesimprovetheantioxidantstatusofhealthyyoung female volunteers without affecting anti-inflammatory parameters: results from the randomised, doubleblind, placebo-controlled, cross-over ANTHONIA (ANTHOcyanins in Nutrition Investigation Alliance) study. Br J Nutr 2014;28;112(6):925-936 doi: 10.1017/ S0007114514001482. 
38. Lee Y., Pham T.X., Bae M., Hu S., O'Neill E., Chun O.K., Han M.J., Koo S.I., Park Y.K., Lee J.Y.: Blackcurrant (Ribes nigrum) Prevents Obesity-Induced Nonalcoholic Steatohepatitis in Mice. Obesity (Silver Spring). 2019;27(1):112-120 doi: 10.1002/oby.22353.

39. Lee Y.M., Yoon Y., Yoon H., Park H.M., Song S., Yeum K.J.: Dietary Anthocyanins against Obesity and Inflammation. Nutrients. 2017;9(10):1089 doi: 10.3390/ nu9101089.

40. Lengsfeld C., Deters A., Faller G., Hensel A.: High molecular weight polysaccharides from black currant seeds inhibit adhesion of Helicobacter pylori to human gastric mucosa. Planta Med 2004;70(7):620-626 doi: 10.1055/s-2004-827184.

41. Li X., Xu J., Tang X., Liu Y., Yu X., Wang Z., Liu $W$. Anthocyanins inhibit trastuzumab-resistant breast cancer in vitro and in vivo. Mol Med Rep. 2016;13(5):4007-4013 doi: 10.3892/mmr.2016.4990.

42. Li X., Zhao J., Yan T., Mu J., Lin Y., Chen J., Deng $H$., Meng $X$ :: Cyanidin-3-O-glucoside and cisplatin inhibit proliferation and downregulate the PI3K/AKT/ mTOR pathway in cervical cancer cells. J Food Sci 2021;86(6):2700-2712 doi: 10.1111/1750-3841.15740.

43. Lin B.W., Gong C.C., Song H.F., Cui Y.Y.: Effects of anthocyanins on the prevention and treatment of cancer. Br J Pharmacol 2017;74(11):1226-1243 doi: 10.1111/ bph.13627.

44. Liu B., Li Z.: Black Currant (Ribes nigrum L.) Extract Induces Apoptosis of MKN-45 and TE-1 Cells Through MAPK- and PI3K/Akt-Mediated Mitochondrial Pathways. J Med Food 2016;19(4):365-373 doi: 10.1089/ jmf.2015.3521.

45. Medzhitov R.: Inflammation 2010: new adventures of an old flame. Cell 2010;140(6):771-776 doi: 10.1016/j. cell.2010.03.006.

46. Medzhitov R.: Origin and physiological roles of inflammation. Nature 2008; 24;454(7203):428-435 doi: 10.1038/nature07201.

47. Nanashima N., Horie K., Chiba M., Nakano M., Maeda H., Nakamura T:: Anthocyanin rich blackcurrant extract inhibits proliferation of the MCF10A healthy human breast epithelial cell line through induction of G0/G1 arrest and apoptosis. Mol Med Rep 2017;16(5):61346141 doi: 10.3892/mmr.2017.7391.

48. Nanashima N., Horie K., Yamanouchi K., Tomisawa T., Kitajima M., Oey I., Maeda H.: Blackcurrant (Ribes nigrum) Extract Prevents Dyslipidemia and Hepatic Steatosis in Ovariectomized Rats. Nutrients 2020;12(5):1541 doi: 10.3390/nu12051541.

49. Nour V., Trandafir I., Ionica M.E.: Ascorbic acid, anthocyanins, organic acids and mineral content of some black and red currant cultivars. Fruits 2011;66(5), 353-362 doi: 10.1051/fruits/2011049.

50. Olejnik A., Kowalska K., Olkowicz M., Juzwa W., Dembczyński R., Schmidt M.: A Gastrointestinally Digested Ribes nigrum L. Fruit Extract Inhibits Inflammatory Response in a Co-culture Model of Intestinal Caco-2 Cells and RAW264.7 Macrophages. J Agric Food Chem 2016;64(41):7710-7721 doi: 10.1021/ acs.jafc.6b02776.
51. Olsson M.E., Gustavsson K.E., Andersson S., Nilsson A., Duan R.D.: Inhibition of cancer cell proliferation in vitro by fruit and berry extracts and correlations with antioxidant levels. J Agric Food Chem 2004;52(24):72647271 doi: 10.1021/jf030479p.

52. Paturi G., Butts C.A., Monro J.A., Hedderley D.: Effects of Blackcurrant and Dietary Fibers on Large Intestinal Health Biomarkers in Rats. Plant Foods Hum Nutr. 2018;73(1):54-60 doi: 10.1007/s11130-018-0652-7.

53. Putta S., Yarla N.S., Peluso I., Tiwari D.K., Reddy G.V., Giri P.V., Kumar N., Malla R., Rachel V., Bramhachari P.V., Reddy D.R.S., Bade R., Mannarapu M., Barreto G.E., Lu D.Y., Tarasov V.V., Chubarev V.N., Ribeiro F.F., Scotti L., Scotti M.T., Kamal M.A., Ashraf G.M., Aliev G., Perry G., Sarker S.D., Rao C.V., Bishayee A.: Anthocyanins: Multi-Target Agents for Prevention and Therapy of Chronic Diseases. Curr Pharm Des 2017;23(41):6321-6346 doi: 10.2174/1381612823666170 519151801.

54.Puupponen-Pimiä R., Nohynek L., Alakomi H.L., Oksman-Caldentey K.M.: The action of berry phenolics against human intestinal pathogens. Biofactors 2005;23(4):243-251 doi: 10.1002/biof.5520230410.

55. Rachtan-Janicka J., Ponder, A., Hallmann, E.: The Effect of Organic and Conventional Cultivations on Antioxidants Content in Blackcurrant (Ribes nigrum L.) Species. Appl Sci 2021;11(11), 5113 10.3390/ app11115113.

56. Rajakariar R., Yaqoob M.M., Gilroy D.W.: COX-2 in inflammation and resolution. Mol Interv 2006;6(4):199207 doi: 10.1124/mi.6.4.6.

57. Reis J.F., Monteiro V.V., de Souza Gomes R., do Carmo M.M., da Costa G.V., Ribera P.C., Monteiro M.C.: Action mechanism and cardiovascular effect of anthocyanins: a systematic review of animal and human studies. J Transl Med 2016;14(1):315 doi: 10.1186/s12967-0161076-5.

58. Röhrig T., Kirsch V., Schipp D., Galan J., Richling E.: Absrorption of Anthocyanin Rutinosides after consumption of a Blackcurrant (Ribes nigrum L.) Extract. J Agric Food Chem 2019;67, 6792-6797 doi: 10.1021/acs.jafc.9b01567.

59. Šavikin K.P., Đorđević B.S., Ristić M.S., KrivokućaĐokić D., Pljevljakušić D.S., Vulić T.: Variation in the fatty-acid content in seeds of various black, red, and white currant varieties. Chem Biodivers 2013;10(1):157165 doi: $10.1002 / \mathrm{cbdv} .201200223$.

60.Schmidt C., Geweke I., Struck S., Zahn S., Rohm $H$.: Blackcurrant pomace from juice processing as partial flour substitute in savoury crackers: dough characteristics and product properties. Int J Food Sci Tech 2018;53(1),237-245 doi:10.1111/ijfs.13639.

61. Serino A., Salazar G.: Protective Role of Polyphenols against Vascular Inflammation, Aging and Cardiovascular Disease. Nutrients 2018;28;11(1):53 doi: 10.3390/nu11010053.

62. Shaw O.M., Nyanhanda T., McGhie T.K., Harper J.L., Hurst R.D.: Blackcurrant anthocyanins modulate CCL11 secretion and suppress allergic airway 
inflammation. Mol Nutr Food Res. 2017;61(9) doi: 10.1002/mnfr.201600868.

63. Sokót-Łętowska A., Kucharska A.Z., Wińska K., Szumny A., Nawirska-Olszańska A., Mizgier P., Wyspiańska D.: Composition and antioxidant activity of red fruit liqueurs. Food Chem 2014;157, 533-539 doi: 10.1016/j. foodchem.2014.02.083.

64. Tańska M., Roszkowska B., Czaplicki S., Borowska E.J., Bojarska J., Dabrowska A.: Effect of Fruit Pomace Addition on Shortbread Cookies to Improve Their Physical and Nutritional Values. Plant Foods Hum Nutr 2016;71(3):307-13 10.1007/s11130-016-0561-6.

65. Teleszko M., Wojdyło A.: Comparison of phenolic compounds and antioxidant potential between selected edible fruits and their leaves. J Funct Food 2015;14,736746 10.1016/j.jff.2015.02.041.

66. Tian .L, Tan Y., Chen G., Wang G., Sun J., Ou S., Chen $W$., Bai $W$ : Metabolism of anthocyanins and consequent effects on the gut microbiota. Crit Rev Food Sci Nutr 2019;59(6):982-991 doi: 10.1080/10408398.2018.1533517.

67. Tian Y., Laaksonen O., Haikonen H., Vanag A., Ejaz H., Linderborg K., Karhu S., Yang B.: Compositional diversity among Blackcurrant (Ribes nigrum) cultivars originating from European countries. J. Agric. Food Chem 2019; 67, 5621-5633 doi: 10.1021/acs.jafc.9b00033.

68. Watson A.W., Okello E.J., Brooker H.J., Lester S., McDougall G.J., Wesnes K.A.: The impact of blackcurrant juice on attention, mood and brain wave spectral activity in young healthy volunteers. Nutr Neurosci 2019;22(8):596-606. doi: 10.1080/1028415X.2017.1420539.

69. Woznicki T.L., Sønsteby A., Aaby K., Martinsen B.K., Heide O.M., Wold A.B., Remberg S.F.: Ascorbate pool, sugars and organic acids in black currant (Ribes nigrum L.) berries are strongly influenced by genotype and post-flowering temperature. J Sci Food Agric 2017;97(4):1302-1309 doi: 10.1002/jsfa.7864.

70. Yamamoto A., Nakashima K., Kawamorita S., Sugiyama A., Miura M., Kamitai Y., Kato Y.: Protective effects of raw and cooked blackcurrant extract on DNA damage induced by hydrogen peroxide in human lymphoblastoid cells. Pharm Biol 2014;52(6):782-788 doi: 10.3109/13880209.2013.836721.

71. Yang B., Zheng J., Laaksonen O., Tahvonen R., Kallio $H$ :: Effects of latitude and weather conditions on phenolic compounds in currant (Ribes spp.) cultivars. J Agric Food Chem 2013;61(14):3517-3532 doi: 10.1021/ jf4000456.

Received: 12.06 .2021

Accepted: 30.07 .2021

Published online first: 11.08.2021 